\title{
Postural reactions of girls and boys aged 12-15 years evaluated using the Romberg test
}

\section{Reakcje posturalne dziewcząt i chłopców w wieku 12-15 lat oceniane testem Romberga}

\author{
Jacek Wilczyński $i^{1}$ Jan Ślężyński² \\ Science, Jan Kochanowski University, Kielce, Poland \\ Head of the Department: Prof. JKU Jacek Wilczyński MD, PhD \\ 2Department of Correction of Posture, the Academy of Physical Education, Katowice, Poland \\ Head of the Department: Prof. Krystyna Gawlik MD, PhD
}

'Department of Neurology, Neurological Rehabilitation and Kinesitherapy, Institute of Physiotherapy, Faculty of Medicine and Health

Key words: postural reactions, stabilographic platform, the centre of feet pressure (COP), mean sway X (MSX), mean sway Y (MSY).

Słowa kluczowe: reakcje posturalne, platforma stabilometryczna, środek nacisku stóp (COP), średnie odchylenie X (SOX), średnie odchylenie Y (SOY).

\begin{abstract}
Introduction: The complex system controlling human posture includes a gaze stabilisation system, which comprises the control of direction and visual acuity during head and body movements, and a posture stabilisation system, keeping the body in balance at rest and in movement.

Aim of the research: To analyse the postural reaction of SOX and SOY using the Romberg test with eyes open (EO) and closed (CE) in girls and boys aged 12-15 years.

Material and methods: The study included 503 students of Primary School No. 13 and School No. 4 in Starachowice. Postural reactions were tested on a Cosmogamma platform by Emildue R50300. Postural reactions were analysed, and mean sway X (MSX) and mean sway Y (MSY) were calculated.

Results: Analysis of variance showed significant differences of MSX only between girls and boys $(p<0.036)$. MSX was significantly lower in girls in both tests with EO and CE. Although there was no apparent significant difference of MSX between the Romberg test with EO and CE, a slight progression was observed in the test with CE. Analysis of variance of MSY with a single classification showed a significant effect of study options $(p<0.048)$, a significant interaction of gender and options of the study $(p<0.048)$, and a significant interaction of age and options of the study $(p<0.026)$. Analysis of variance of MSY showed a significant progression of MSY in the test with CE.

Conclusions: Our research showed that balance with CE does not worsen, so it can be assumed that children have limited skills of using vision to maintain balance because there is a lack of appropriate coordination between vision and motor abilities, which in children are in development.
\end{abstract}

\section{Streszczenie}

Wprowadzenie: W złożonym systemie kontrolującym postawę wyodrębnia się układ stabilizujący spojrzenie, na który składa się kontrola kierunku i ostrości widzenia podczas ruchów głowy i całego ciała, oraz układ stabilizujący postawę, utrzymujący ciało w równowadze w spoczynku i ruchu.

Cel pracy: Analiza reakcji posturalnych SOX i SOY testem Romberga z oczami otwartymi (OE) i zamkniętymi (CE) dziewcząt i chłopców w wieku 12-15 lat.

Materiał i metody: Badaniami zostało objętych 503 uczniów Szkoły Podstawowej nr 13 i Gimnazjum nr 4 w Starachowicach. Reakcje posturalne badano na platformie Cosmogamma by Emildue R50300. Analizowano reakcje posturalne, średnie odchylenie X (SOX) i średnie odchylenie Y (SOY).

Wyniki: Analiza wariancji wykazała istotne zróżnicowanie SOX jedynie między dziewczętami a chłopcami $(p<0,036)$. SOX było istotnie mniejsze u dziewcząt zarówno w teście OE, jak i CE. Analiza wariancji SOY z klasyfikacją pojedynczą wykazała istotny efekt opcji badania $(p<0,048)$, istotną interakcję płci i opcji badania $(p<0,048)$ oraz istotną interakcję wieku i opcji badania $(p<0,026)$. Analiza wariancji SOY wykazała istotną progresję SOY w badaniu CE. 
Wnioski: Nasze badania wykazały, że równowaga z oczami zamkniętymi nie ulega pogorszeniu, w związku z tym można sądzić, że dzieci mają ograniczone umiejętności wykorzystania wzroku w utrzymaniu równowagi. Nie ma bowiem odpowiedniej koordynacji między wzrokiem a zdolnościami motorycznymi, które u dzieci znajdują się w rozwoju.

\section{Introduction}

Balance is a state of the postural system, which has vertical orientation of the body achieved by balancing the forces and their moments. Balance is provided by the nervous system through reflexive tension of appropriate muscles called postural or anti-gravity [1, 2]. All living beings are in a relationship with gravity. It gives a sense of the centre of gravity in space, time, motion, depth, and self-awareness. The balance mechanism allows monitoring of all sense perceptions between the body and the brain. Problems with balance are transferred to the other sensory systems, since all impressions before being passed on to the central nervous system (CNS) pass through the vestibular system at the brain stem. The task of postural system is:

- to provide current data on the position of the body in space, the direction and speed of its movement,

- rapid prevention of fall reaction correcting any deviation of the centre of gravity from the equilibrium position within the base,

- control of eyeball in order to maintain the correct image of the surrounding area during the movement of a person, his/her environment, or both simultaneously [3-10].

The complex system controlling posture consists of a gaze stabilisation system, which comprises the control of direction and visual acuity during head and body movements, and a posture stabilisation system, keeping the body in balance at rest and in movement. Both systems - gaze stabilisation and posture stabilisation - have different sources of receptor information, information about motor reactions of various parts of the body movement, and the involvement of different pathways in the CNS. They are closely interdependent because gaze stabilisation is not possible as long as the body and head with the eyeballs are not stable. However, correct vision dependent on a stable perspective is one of the basic senses enabling control and stabilisation of posture. In the process of gaze stabilisation are involved: vestibulo-ocular reflex (VOR), mechanisms of any tracking, saccadic eye movements (jumping movements of high-frequency), and the fixation reflex. Vestibulo-ocular reflex stabilises the gaze during rapid movements of the head, and is of less importance in slow movements - then free tracking mechanisms take control of the gaze, which do not depend on information coming from the vestibular system. For their normal functioning visual information is needed regarding the position of the tracked object. Saccadic eye movements help to capture the loss of sight object again. Keeping the image of the tracked object within macula flava is maintained by fixation reflex. A key role in the reflex oculomotor responses, and largely in postural ones, is played by the peripheral vestibular organ [3], which through vestibulo-spinal reflexes (VSR) also affects skeletal muscle function. This influence is manifested by counteracting gravity forces, stimulating muscle reactions that keep the body in balance during movement and maintenance of muscle tension at rest. Skeletal muscle tensions are mainly governed by impulses from otolith organs. Their effectors are antigravity muscles, neck, trunk, and limb rectifiers. The tension of these muscles is also, to a lesser extent, affected by cupula organs (sacculus and utriculus) [3]. There are three types of these reactions:

- reactions ensuring the stability of the adopted posture and supporting the correct position of the limbs (static responses)

- reactions that allow adoption of the correct posture after improper position (setting or righting reflexes), - reactions ensuring body balance when changing the position of the centre of gravity (balance reflexes) [3].

All postural reflexes are of coupled nature and they complement each other. However, they do not always occur at equal power. Static and setting reflexes are the most significant in infancy when they are of real nature, then they undergo some slowdown. Balance reflexes intensify with ontogenetic development. There are some similarities in the triggering mechanisms and effect on muscles of VOR and VSR. Some attention is drawn to the analogical mechanism of stimulation and inhibition controlling the balance between flexors and extensors on both sides of the body and oculomotor muscles: rectus, lateral and medial in two eyeballs. The main difference between the organisation of VOR and VSR reflexes is the complexity of the muscle response induced by spinal reflexes. Even the simplest movement performed in a single joint requires the interaction of many muscles, in which, at one time, there is an increase or decrease of tension. Agonist and antagonist muscles must simultaneously receive signals that provide smooth movement. The vestibular organ affects skeletal muscle function through three main routes: lateral vestibular-spinal, medial vestibular-spinal, and reticular-spinal, which supports the two previous ones. The first two are directly from neurons in the vestibular nuclei, while the third is formed by reticular neurons, stimulated by the vestibular organ. Activation of nerve fibres carried through a lateral atrio-core pathway, in the lateral vestibular nucleus causes stimulation of extensor motoneurons and inhibition of flexor motoneurons on the same side. Neurons running through the medial 
atrio-core pathway usually end at the level of the cervical segments of spinal cord. This pathway plays an important role in the coordination of cervical-vestibular-oculomotor reflexes. The impact of the vestibular organ on the muscles is additionally regulated by the cerebellum. It regulates the reactions of skeletal muscles formed in response to stimulation of the vestibular organ. It is treated as a coordination centre of movements receiving information from all somatoreceptors of the head, trunk, and limbs [4].

\section{Aim of the research}

The aim of the study was to analyse postural sways MSX and MSY in the Romberg test (OE - CE) in girls and boys aged 12-15 years. The basic principle of stabilographic studies using a stabilographic platform are continuous measurements of the point of application of the resultant reaction forces of the base called the centre of foot pressure (COP). One of the parameters of the stabilogram is the mean sway X (MSX). This is the average oscillation along the $\mathrm{X}$ axis and mean lateral swings, i.e. the average distance between the extreme swings of the centre of foot pressure in the frontal plane. The mean sway Y (MSY) is the average oscillation along the $\mathrm{Y}$ axis, the average anteriorposterior swing, i.e. the average distance between the extreme swings of the centre of foot pressure in the sagittal plane. The smaller the parameters, the more accurate the process of postural control [1].

\section{Material and methods}

The studies included 503 students aged $12-15$ years, therein 247 (49.1\%) girls and 256 (50.9\%) boys from earlier, randomly selected schools: Primary School No. 13 and Secondary School No. 4 in Starachowice. There were 60 (24.29\%) 12-year-old girls, also 60 (24.29\%) 13 -year-old girls, 65 (26.32\%) 14-year-old girls, and 62 (25.10\%) 15-year-old girls. There were 65 12-year-old boys (25.39), 61 13-year-old boys (23.83\%), 60 14-yearold boys (23.44\%) and 7015 -year-old boys (27.34\%). Size distributions by age and sex groups did not differ significantly. The study was performed in November and December 2005. For the balance tests a Cosmogamma platform by Emildue R50300 was used (Figure 1) [11]. The Romberg test consisted of two consecutive trials lasting $30 \mathrm{~s}$ : the first with eyes open (OE), the other with closed eyes (CE) [12]. Each person was carefully instructed in the course of the test. Silence was provided during the test, because auditory stimuli acting on the man under conditions of focus can significantly affect postural reflexes. The tested person was also assured of the total harmlessness of the test being performed. During the test the researcher studied all the time behind the test person without giving any information. When testing with EO the tested person was asked to focus the eye on the reference point located on the screen of the computer. The centre of macular

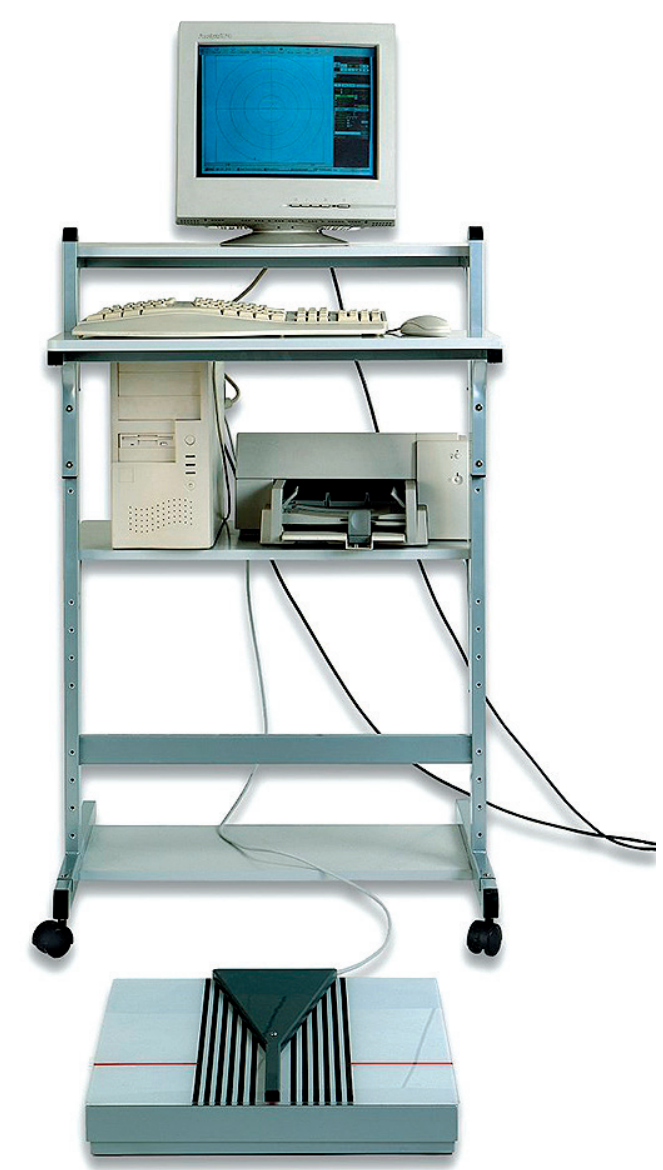

Figure 1. Cosmogamma stabilographic platforma by Emildue R50300 [11]

vision was within one metre of the tested person. Before starting the test with CE the examiner made sure that the test person was able to maintain an upright posture without a visual control. The test was carried out on the platform barefoot because shoes could have disturbed the posture. Feet were set with careful precision: heels $2 \mathrm{~cm}$ apart, feet set at an angle of $30^{\circ}$, so that the centre of gravity of the polygon base $(\mathrm{O})$ was in the sagittal axis of the platform within $4 \mathrm{~cm}$ of its centre (C). The intersection of the vertical and horizontal axes corresponding to the position of ankles coincided with the center of the platform $(\mathrm{C})$ indicated on the screen as the centre of a static and dynamic diagram. To facilitate the correct settings of the tested person, the platform was equipped with standard pattern of feet spacing. The test took and maintained his or her position with lowered arms at his or her sides and upright head. The examiner first checked the coordinates of the center of pressure (COP) on the screen, and then after their stabilisation determined the most appropriate scale of sensitivity. At the time of adoption of a stable position by the student the test started and the route of the deflection of the COP was displayed on the screen. To describe 
the balance, MSX and MSY were used. The smaller the parameters, the more accurate the process of postural control. The dependent variables were the postural reactions MSX and MSY, and independent variables were gender, age, and repeated measurements of the following options: open eyes/eyes closed (OE/CE).

\section{Statistical analysis}

Arithmetic means $(x)$ and standard deviations (s) were calculated, analysis of variance with a single and double classification, Kruskal-Wallis and Kolmogorov-Smirnov tests, and Bonferoni post-hoc analysis were used [13].

\section{Results}

The mean body height of the girls was $161.45 \mathrm{~cm}$, the mean weight was $50.84 \mathrm{~kg}$, and mean body mass index (BMI) was $19.43 \mathrm{~kg} / \mathrm{m}^{2}$. The mean body height of boys was $165.41 \mathrm{~cm}$, mean weight was $52.74 \mathrm{~kg}$, and mean BMI was $19.08 \mathrm{~kg} / \mathrm{m}^{2}$. MSX of all subjects ranged from $2.73 \mathrm{~mm}$ in the test with OE to $2.78 \mathrm{~mm}$ with CE. MSX of the girls was from $2.71 \mathrm{~mm}$ in the test with EO to $2.61 \mathrm{~mm}$ with CE. The MSX of the boys was from $2.75 \mathrm{~mm}$ in the Romberg test with EO to $2.94 \mathrm{~mm}$ with CE. In the Romberg test with EO MSX was the lowest in 12 -year-old girls, then 15,13 , and 14 -year-olds, while with CEMSX was the lowest in 13-year-old girls, then 14, 15 and 12-year-old. In the same test with OE MSX was the lowest in 12-year-old boys, then 15, 14, and 13-yearolds, while with CE MSX was the lowest in 14-year-old boys, then 15, 12, and 13-year-olds. With CE MSX increased only in 12-year-old girls and all boys. MSX was lower in girls in both tests with eyes closed and open. In the Romberg test MSY of all subjects oscillated from $4.54 \mathrm{~mm}$ with EO to $3.79 \mathrm{~mm}$ with CE; in girls from $4.61 \mathrm{~mm}$ with $\mathrm{EO}$ to $3.61 \mathrm{~mm}$ with CE; and in boys from $4.47 \mathrm{~mm}$ with eyes open to $3.97 \mathrm{~mm}$ with CE. In the Romberg test with EO MSY was the smallest in 15 -year-old girls, then 12, 13, and 14-year-olds; while with CE MSY was the smallest in 15-year-old boys, then 13, 12, and 14-year-olds. In the Romberg test with EO MSY was the smallest in 15-year-old boys, then 12, 14, and 13-year-olds. In the Romberg test with CE MSY decreased in all of the girls, while progression occurred only in 12-year-old boys. In the Romberg test with EO MSY was slightly higher in girls, but with eyes closed MSY was slightly higher in boys.

\section{Discussion}

Analysis of variance showed significant differences of MSX only between girls and boys ( $p \leq 0.036)$. MSX was significantly lower in girls in both tests,

Table 1. Analysis of variance with a single classification of MSX and MSY including gender, age, and study options

\begin{tabular}{|c|c|c|c|c|c|c|}
\hline \multicolumn{7}{|c|}{ Analysis of variance with a single classification of MSX } \\
\hline Independent variables & $\begin{array}{c}\mathrm{d} f \\
\text { effect }\end{array}$ & $\begin{array}{c}\text { MS } \\
\text { effect }\end{array}$ & $\begin{array}{c}\mathrm{d} f \\
\text { error }\end{array}$ & $\begin{array}{l}\text { MS } \\
\text { error }\end{array}$ & $F$ & $P$-value \\
\hline Gender (1) & 1 & 9.286 & 495 & 2.092 & 4.438 & 0.036 \\
\hline Age (2) & 3 & 1.002 & 495 & 2.092 & 0.479 & 0.696 \\
\hline Study option (3) & 1 & 0.512 & 495 & 1.508 & 0.339 & 0.560 \\
\hline Interaction of gender and age (1/2) & 3 & 1.068 & 495 & 2.092 & 0.510 & 0.675 \\
\hline Interaction of gender and study option (1/3) & 1 & 4.752 & 495 & 1.508 & 3.150 & 0.076 \\
\hline Interaction of age and study option (2/3) & 3 & 2.174 & 495 & 1.508 & 1.441 & 0.229 \\
\hline Interaction of gender, age, and study option (1/2/3) & 3 & 0.114 & 495 & 1.508 & 0.076 & 0.972 \\
\hline \multicolumn{7}{|c|}{ Analysis of variance with a single classification of MSY } \\
\hline Independent variables & $\begin{array}{c}\mathrm{d} f \\
\text { effect }\end{array}$ & $\begin{array}{c}\text { MS } \\
\text { effect }\end{array}$ & $\begin{array}{c}\mathrm{d} f \\
\text { error }\end{array}$ & $\begin{array}{l}\text { MS } \\
\text { error }\end{array}$ & $F$ & $P$-value \\
\hline Gender (1) & 1 & 3.582 & 495 & 5.442 & 0.658 & 0.417 \\
\hline Age (2) & 3 & 4.420 & 495 & 5.442 & 0.812 & 0.487 \\
\hline Study option (3) & 1 & 146.35 & 495 & 3.541 & 41.325 & 0.001 \\
\hline Interaction of gender and age (1/2) & 3 & 1.854 & 495 & 5.442 & 0.340 & 0.795 \\
\hline Interaction of gender and study option (1/3) & 1 & 13.967 & 495 & 3.541 & 3.943 & 0.048 \\
\hline Interaction of age and study option (2/3) & 3 & 11.059 & 495 & 3.541 & 3.122 & 0.026 \\
\hline Interaction of gender and age and study option (1/2/3) & 3 & 5.287 & 495 & 3.541 & 1.493 & 0.215 \\
\hline
\end{tabular}


with OE and CE. The lower the MSX, the more perfect the process of postural control (Table 1). Analysis of variance of MSY with a single classification showed a significant effect of study options ( $p \leq 0.001)$, a significant interaction of gender and options of the study ( $p \leq 0.048$ ), and a significant interaction of age and options of the study ( $p \leq 0.026)$ (Table 1). For these reasons, a further analysis of variance of MSY was performed with a double classification. It showed a significant effect of study options in the Romberg test with EO and CE $(p \leq 0.001)$ and a significant interaction of gender and options of the study $(p<0.037)$ (Table 2, Figure 2). These interactions justified the performance of post-hoc analysis Bonferoni test of MSY. It showed significant differences among girls in the Romberg test with EO $(p \leq 0.001)$ and $(p \leq 0.001)$, among boys with CE $(p \leq 0.017)$, and between girls and boys with OE $(p<0.001)$ and CE $(p<0.004)$. Double analysis of variance of MSY showed a significant effect of study options $(p<0.001)$ and a significant interaction of age and study options (OE/CE) $(p \leq 0.020)$ (Table 3, Figure 3). The above interactions justified post-hoc analysis of MSY (Bonferoni test). It showed significant differences in the Romberg test among 12-year-old girls with CE and 13-year-old girls with EO ( $p \leq 0.008)$, between 13-year-old girls with $\mathrm{EO}$ and CE ( $p \leq 0.001)$, and between the 13-year-old and 14-year-old girls in the Romberg test with EO and CE ( $p \leq 0.001)$. There were also significant differences in the Romberg test between 14-year-old girls with EO and CE ( $p \leq 0.003)$, between the 14-year-old girls with $\mathrm{CE}$ and 13-year-olds with EO $(p \leq 0.001)$ and between the 15-year-old girls with $\mathrm{CE}$ and 13-year-olds with CE $(p \leq 0.001)$. Post-hoc analysis of MSY also showed significant differences in the Romberg test between 13-year-old boys with EO and 12-year-old with CE ( $p \leq 0.001$ ), between the 13-year-old boys with EO and CE $(p \leq 0.001)$ between the 13-year-old boys with CE and the 12-year-olds with EO ( $p \leq 0.003)$, between the 14 -year-old boys with EO and the 12-year-olds with CE $(p \leq 0.004)$, between the 14 -year-old boys with EO and 13-year-olds with CE $(p \leq 0.017)$, between the 14-year-old boys with $\mathrm{CE}$ and 12-year-olds with CE ( $p \leq 0.004)$, between the 15 -year-old boys with CE and 12 -year-olds with EO ( $p \leq 0.018)$. In our previous studies (2005) significant differences in the Romberg test became apparent in length path (LP), mean load point X (MLPX), lateral speed (LS), and MSY with both OE and CE. Only mean load point X (MLPX)

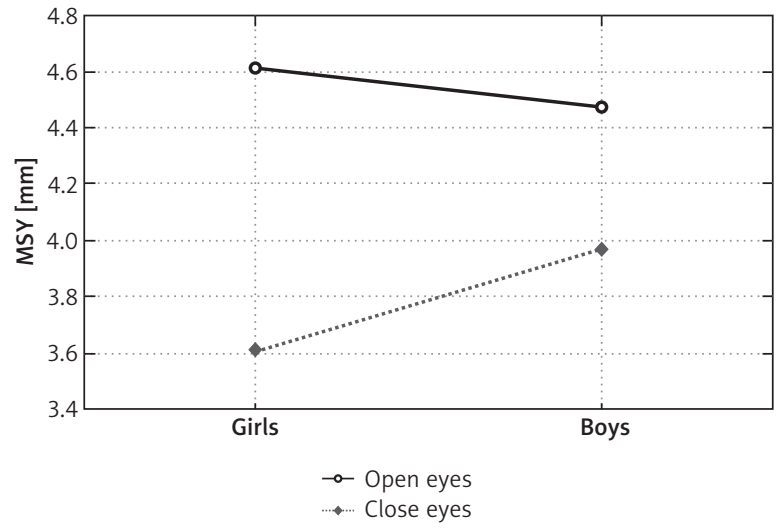

Figure 2. Mean sway Y (MSY) and gender

in the test with CE increased. Reduction of most parameters of COP with CE can be explained by the fact that in the case of temporary lack of visual control of the test person there was better focus and attention on the work being done. A characterising feature is also the relatively small effect of vision on the variability of COP signal. Our research shows that if the parameters of the balance with CE are not subject to deterioration, one can talk about the lack of ability of using vision in the process of maintaining the balance by children. There is no proper coordination between the sight and the motor system, which in children is in development $[4-6,14]$. Closing eyes usually causes bigger sways [15-20]. There are interesting studies about a compensatory role of vision in maintaining balance in people with sensory and vestibular system impairments. They showed deterioration of body stability after short-term exclusion of vision control [14]. In free standing, visual information usually has a strong stabilising effect on maintaining position, and momentary exclusion of vision causes a change in the number and amplitude of sways. Vision is the main source of information in people with vestibular system or proprioceptive sense impairments [21-23].

\section{Conclusions}

The analysis of variance showed significant differences of MSX only between girls and boys. The MSX was significantly lower in girls in both tests, with OE and CE. The smaller the MSX, the better the process of postural control. Although there was no signifi-

Table 2. Analysis of variance with a double classification of MSY including gender and study options

\begin{tabular}{|lcccccc|}
\hline Independent variables & $\mathrm{d} f$ effect & MS effect & $\mathrm{d} f$ error & MS error & $\boldsymbol{F}$ & $P$-value \\
Gender (1) & 1 & 3.163 & 501 & 5.414 & 0.584 & 0.444 \\
Study option (2) & 1 & 142.05 & 501 & 3.599 & 39.468 & 0.001 \\
Interaction of gender and study option (1/2) & 1 & 15.732 & 501 & 3.599 & 4.371 & 0.037 \\
\hline
\end{tabular}


Table 3. Analysis of variance with a double classification of MSY including age and study option

\begin{tabular}{|lcccccc|}
\hline Independent variables & $\mathrm{d} f$ effect & MS effect & $\mathrm{d} f$ error & MS error & $\boldsymbol{F}$ & $P$-value \\
Age (1) & 3 & 4.295 & 499 & 5.417 & 0.792 & 0.498 \\
Study option (2) & 1 & 143.77 & 499 & 3.574 & 40.225 & 0.001 \\
Interaction of age and study option (1/2) & 3 & 11.786 & 499 & 3.574 & 3.297 & 0.020 \\
\hline
\end{tabular}

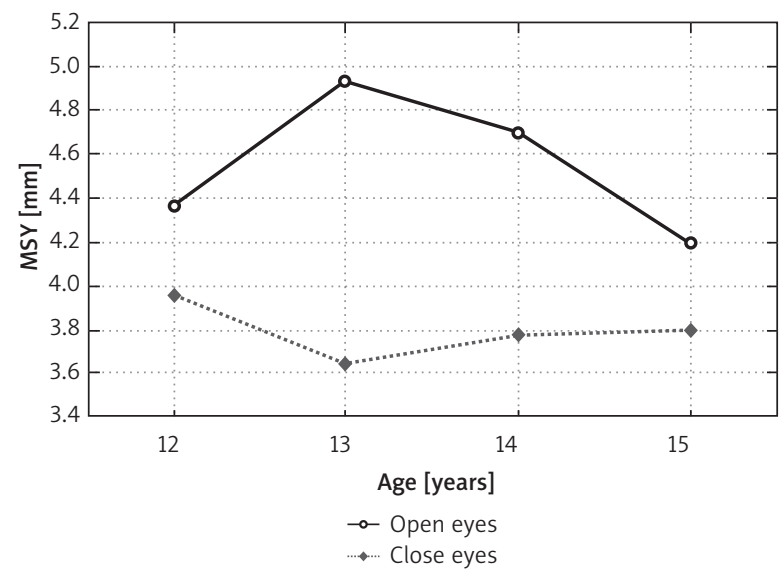

Figure 3. Mean sway Y (MSY) and age

cant difference between MSX between the Romberg test with EO and closed, in the test with eyes closed a slight progression was observed. The analysis of variance of MSY with a single classification showed a significant effect of study options, significant interaction of gender and study options, and a significant interaction of age and study options. The analysis of variance of MSY showed a significant increase of MSY in the test with CE. The results support the view that even if the parameters of balance with CE are not subject to deterioration, it means that children do not yet have the proper abilities to use vision to maintain balance. There is no proper coordination between the eye and the motor system, which in children are still in development.

\section{Conflict of interest}

The authors declare no conflict of interest.

\section{References}

1. Błaszczyk JW. Biomechanika kliniczna. Podręcznik dla studentów medycyny i fizjoterapii. PZWL, Warsaw 2004.

2. Błaszczyk JW. Modele cybernetyczne wybranych struktur układu nerwowego. In: Neurocybernetyka teoretyczna. Tadeusiewicz R (ed). WUW, Warsaw 2009.

3. Held-Ziółkowska M. Równowaga statyczna i dynamiczna ciała. Cz. 1. Organizacja zmysłowa i biomechanika układu równowagi. Mag Otorynolaryngol 2006; 2: 39-46.
4. Wilczyński J. Reakcje równoważne na przykładzie prędkości przednio-tylnej posturogramu u dziewcząt i chłopców w wieku 12-15 lat. Studia Medyczne 2010; 26: 13-8.

5. Wilczyński J, Wilczyński I. Reakcje posturalne dziecka ze skoliozą idiopatyczą badanego na platformie stability system tecnobody. Fizjoter Pol 2013, 2: 48-54.

6. Wilczyński J, Lipińska-Stańczak M, Szaraniec K. Body posture defects and the speed of the center of feet pressure in children of school age. Studia Medyczne 2014; 30: 156-61.

7. Golema M. Charakterystyka procesu utrzymywania równowagi ciała człowieka $\mathrm{w}$ obrazie stabiliograficznym. AWF, Wrocław 2002.

8. Juras G. Koordynacyjne uwarunkowania procesu uczenia się utrzymania równowagi ciała. AWF, Katowice 2003.

9. Juras G, Waśkiewicz Z, Raczek J (eds.). Current research in motor control II. Theories, implementations and research perspectives in motor control. AWF, Katowice 2004.

10. Nashner LM, Peters JF. Dynamic posturography in the diagnosis and management of dizziness and balance disorders. Neurol Clin 1990; 8: 331-49.

11. Available at: www. Technomex.pl, 2005.

12. Romberg $\mathrm{MH}$. Lehrbuch der Nervenkrankheiten des Menschen. Berlin 1851.

13. Komputerowy program statystyczny: Statistica 7.1 statsoft 2007.

14. Kuczyński M. Model lepko-sprężysty w badaniach stabilności postawy człowieka. AWF, Wrocław 2003.

15. Hughes MA, Duncan PW, Rose PT, Chandler JM, Studenski SA. The relationship of postural sway to sensorimotor function, functional performance, and disability in the elderly. Arch Phys Med Rehabil 1996; 77: 567-72.

16. Sipko T, Skolimowski T, Ostrowska B. Wpływ chwilowej i trwałej utraty kontroli wzrokowej położenia ciała $\mathrm{w}$ przestrzeni na proces regulacji równowagi ciała w pozycji stojącej. Fizjoterapia 1997; 5: 11-6.

17. Sipko T. Regulacja równowagi ciała $\mathrm{w}$ pozycji stojącej u osób z upośledzeniem narządu wzroku lub słuchu. AWF, Wrocław 1998.

18. Brooke-Wavell K, Athersmith LE, Jones PR, Masud T. Brisk walking and postural stability. A cross-sectional study in postmenopausal women. Gerontology, 1998; 44: 288-92.

19. Danion F, Boyadjian A, Marin L. Control of locomotion in expert gymnasts in the absence of vision. J Sport Social Issues 2000; 18: 809-14.

20. Dudek J. Wpływ elektrostymulacji mięśni grzbietu na umiejętność utrzymania równowagi u osób z uszkodzeniem słuchu. AWF, Kraków 2001.

21. Collins JJ, De Luca CJ. Open-loop and closed-loop control of posture: a random-walk analysis of center of pressure trajectories. Exp Brain Res 1993; 95: 308-18.

22. Collins JJ, De Luca CJ. The effects of visual input on openloop and closed-loop postural control mechanisms. Exp Brain Res 1995; 103: 151-63. 
23. Gurfinkel VS, Ivanenko YP, Levik YS, Babakova IA. Kinesthetic reference for human orthograde posture. Neuroscience 1995; 68: 229-43.

\section{Address for correspondence:}

Prof. JKU Jacek Wilczyński MD, PhD

Department of Neurology, Neurological Rehabilitation and Kinesitherapy

Institute of Physiotherapy

Faculty of Medicine and Health Science

Jan Kochanowski University

ul. Żeromskiego 5, 25-369 Kielce, Poland

Phone: +48 603703926

E-mail: jwilczynski@onet.pl 